\title{
Meglena Zlatkova
}

Department of Ethnology

Paisii Hlendarski University, Plovdiv

m_zlatkova@yahoo.com

\section{Gardening the City ${ }^{1}$ : Neighbourliness and Appropriation of Common Spaces in Bulgaria}

\begin{abstract}
The paper discusses the forms of public-private space division in a post-socialist Bulgarian city as everyday practices of inhabiting and appropriation of common spaces in one neighborhood of Plovdiv. The author's anthropological research of urban spaces has included long-term observation of everyday practices in the city of socialism, the city in transition and the changed cities nowadays, following the line of the changing boundaries, distinction and expression of the public and the private, the common and the individual. Of particular interest in my research are the forms of transgression of the physical borders and social boundaries and of establishing new ones, according to the changing identities, social hierarchies, power relations, as well as forms of social solidarity, networking and investment in social capital. The paper presents cases of blurring borders and boundaries as urban discourses - of the socialist city, the city in transition and the city after 2007, when Bulgaria joined the EU. These cases are studied on the base of everyday practices of urban gardening in common spaces - around blocks of flats, on the windowed balconies, and in small gardens (vegetable plots) in the town outskirts.
\end{abstract}

Keywords: city, neighbourhood, urban gardening, inhabiting spaces, Bulgaria

\footnotetext{
1 The distinction between city and town is not essential in the Bulgarian context - this paper uses both terms. I am very grateful to Vitana Kostadinova for her help with translation and editing of the paper.

This is an Open Access article distributed under the terms of the Creative Commons Attribution 3.0 PL License (creativecommons.org/licenses/by/3.0/pl/), which permits redistribution, commercial and non-commercial, provided that the article is properly cited. (C) The Author(s), 2015

Publisher: Institute of Slavic Studies, Polish Academy of Sciences

Editor in chief: Jolanta Sujecka

Conception and academic editing of this issue: Maciej Falski
} 
7 he garden is an urbanized image of nature in the inhabited space of urban dwellers. The garden is also a mirror image of a certain society; the garden is a heterotopia in Michel Foucault's sense; and, last but not least, the garden is a marginal space, negotiating the boundaries between "us" and "them," here and somewhere else, the artificial and the natural. The initial mythological opposition between nature and culture in the modern and post-modern urban environment provokes questions as to the ways of appropriating shared spaces, modes of civic participation, and the division between the public and private, rural and urban, etc.

Gardens, despite being "des éspaces autres," the other spaces (Foucault, 1984), ${ }^{2}$ are part of the shared urban space. This text brings into focus the gardens of a residential area as a tool that problematizes the negotiations between what is public and what is private in Bulgarian cities and towns. At the outset of my paper I would like to propose the topic of "gardening the city" as a means to study the forms of appropriation of space on the level of changing official discourses and everyday practices in Bulgarian cities and towns, ${ }^{3}$ offering a tool to approach contemporary Bulgarian urban situation of negotiating spaces and sharing common urban environment. My reflections are based on long-term anthropological participant observation of everyday practices in some Bulgarian cities and towns, ${ }^{4}$ as well as on analyses of urban polices and management strategies. What could be observed nowadays as gardening the city is, on the one hand, urban gardening and, on the other, the municipal policies and practices that highlight the idea of cities and towns as green spaces and nice places for living. And, because the city (town) is also an inherited space, I will discuss gardening as the "occurrence" of a city (town) between its "topdown" planning and "bottom-up" making: as an interaction between an objectified sociality, inscribed in the physical framework and established

\footnotetext{
2 The garden is a heterotopia, which is "capable of juxtaposing in a single real place several spaces, several sites that are in themselves incompatible. [...] The garden is the smallest parcel of the world and then it is the totality of the world" (Foucault, 1984).

A initial version of this text was presented at the $12^{\text {th }}$ international congress of the International Society for Ethnology and Folklore (SIEF), which took place in Zagreb, 21-25 June 2015 under the title Utopias, Realities, Heritages. Ethnographies for the 21st century. My participation in the event was inspired and supported by a project entitled City-making: space, culture and identity (CITID), funded by the Croatian Science Foundation for the period 2014-2018, in which I am currently engaged with Dr Jasna Čapo Žmegač, as its research advisor and Dr Valentina Gulin Zrnić, both of the Institute of Ethnology and Folklore Research, Croatian Academy of Sciences.

4 The results of this research were published in its entirety in 2012 under the title Ethnosociology of the City. The Case of Plovdiv (Zlatkova, 2012).
} 
context, as well as codification of behaviour, on the one hand, and on the other hand - the specific habitat and interiorised sociality (urban habitus in Pierre Bourdieu's terminology), i.e. the ability of the urban residents to appropriate and produce the city through their activities, practices, symbols, etc.

Thus, we come to the topic of urban gardening as urban heritage, at once visible and invisible, and the urban space as a palimpsest ${ }^{5}$ that retains the layers of earlier times and previous urban situations. Using this approach to study the "happening" of the city between the "top" and the "bottom," I will distinguish between two layers of gardening the city: as a municipal policy that implies the official discourse of the social agenda current at a certain point in time, and the urban gardening carried out by individuals in their residential areas. The biographies, practices, visions and life-strategies of those individuals will also come into the limelight. In an attempt to outline the dynamics of the urban situation and the negotiation of space, I put forward a discussion of the forms of urban gardening in a residential area, which is used as a laboratory for anthropological observation.

In order to illustrate everyday gardening and to discuss the contested and/or blurred boundaries between what is public and what is private, let me trace how individuals use common spaces for gardening - established practices are manifested in three different forms, in accordance with the changing regulations of property relations and citizenship. ${ }^{6}$ Using again the heterotopia figure, I consider the urban garden as a place that contains different spaces (socialist, transitional, and EU-framed). These activities are regulated by local legislation but the variations come as a result of individual and/or collective efforts in residential areas, where property around the blocks of flats is either private or municipal. There are also the so-called "vegetable plots" - pieces of land, mainly in the urban outskirts, which individuals have rented from the municipality for long-term use. In the contemporary model of urban gardening, there are chronological distinctions in the uses

5 Different levels of urban phenomena co-exist simultaneously in the heterogeneous space of the city and in this sense it can be thought of as a palimpsest. A palimpsest, from the Greek palimpsēstos ("scraped again"), is an old manuscript, written on top of an erased previous text on a parchment. The "peeling" or "scraping" off of the top layers of the city text has been used as a research strategy when studying the "inhabited," "happening" city in transition in order to "shed light" on what has been hidden. Different temporal and spatial layers might thus "meet up" to throw into relief the "pieces of the city": the grand city, illuminated by power, and the invisible world of the everyday city (Zlatkova, 2011).

6 Chronologically, the distinction can be traced from the socialist period (when users had to cooperate with the local and state administration), through a period of transition (in which property was both private and municipal), and into the contemporary period (after 2007 the rights and obligations of users were clearly defined within the framework of private and municipal property). 
of space, which refer us to the city of socialism, the city of transition, and the EU city (after 2007, when Bulgaria became a member of the EU).

\section{The neighbourhood as a laboratory for urban research}

The real feel of the residential area is inscribed in the urban reality and in the cityscape (townscape); it is also the bearer of marks that denote the historical accumulation of the local. Nevertheless, life in a residential area has its specific dimension as a variety of forms that are micro-local. The configuration of old and new residential areas, villages appropriated by the urban texture, and real estate development in the urban periphery creates a pattern and marks the specificity of cities and towns. The local dimensions of a residential area or a housing estate are a reflection of the city (town) and at the same time a part of it.

Residential areas are both physical and social constructions, each one of them has its own images and places of memory, each can be a site of the collective memory of a community, a family or of all urban residents. Thus, a residential area is a living space, a spatial and human entity, a togetherness of collective life, a framework of meanings created by its citizens. Yet, all these premises must be constantly questioned because a residential area is both universal and specific, characterised by the local and encompassing the entire city (town) within itself. We do not discuss residential areas in general, we are rather interested in the residential areas of Plovdiv, Sofia, Chicago, Paris, Beirut, etc.

Trakia is a place of universality and locality in this text, the latest residential area in Plovdiv, with a forty-year history. It is the third biggest administrative unit in Plovdiv and the youngest in terms of the residents' average age. It boasted 52,506 residents in 2011 - i.e. $15 \%$ of all Plovdivians. ${ }^{7}$ The residential area and the suburb are specific versions of the city, in which the inhabitants are limited by the physical framework and function in social relations established by the architecturally defined spaces. In the Bulgarian case, it is also a specific social experiment, reflecting the socialist idea of a city and its society, in which an initially constructed space, i.e. multi-storey blocks of flats and very few shared places meant for social communication, was populated by a variety of people who did not know each other.

The model of a socialist residential area $^{8}$ was the socialist city with the new type of citizen projected into it. A model of the Trakia residential area

The data is according to the latest poll carried out by the National Statistical Institute in 2010.

8 For more details on housing policy and urban dwelling in the period of socialism and after 1989, see: Parusheva, Marcheva, and Zlatkova (2010). 
after 1989 could be sought in the simultaneous co-existence of the two types of organisation: it is perceived as urban periphery by Plovdivians but also as a relatively independent entity, as a city with its own neighbourhoods, according to administrative division. Unlike other residential areas, Trakia emerged on new territory with no memory of its own, with no "traditional" dwellers. Therefore, it had to be legitimised as a part of the city not only for the people who lived there but also for all Plovdivians.

Residential areas similar to Trakia exist in Western Europe, too, but the specificity of the Bulgarian case stems from the unprecedented intermixing of diverse groups of people. The leading principle of the then dominant ideology was that the differences between rural and urban life needed to be obliterated in order to homogenise the population. The anticipated result had to do with social changes, achieved by introducing elements of the urban style of life, improving on the culture of life and work, the specialisation of labour, etc. Accommodating people in the new residential areas was a function of the state housing policy of that period. Homogenising the population had as its objectives their integration and the overcoming of the cultural, social and ethnic specificities or differences between the individuals. On the other hand, this was an educational process on the topic of the lesson was "how to become an urban resident and a citizen of a modern state," a citizen, as it were, of a model block of flats. When the newly arrived migrants settled in Trakia, ${ }^{9}$ it transpired that one of the places where the models of the rural and the urban coexist is the small garden in front of the block of flats; the garden provides the common ground between dwelling in a house and inhabiting a flat. Trakia was built on a terrain that was entirely owned by the municipality and the state because all land had been nationalised and the state was its sole proprietor in that period; thus, the places which accommodated the gardens were inevitably shared spaces.

\section{Urban gardening as a compensation for the shortages in socialist cities and towns}

The period of socialism in Bulgaria, as in many other countries, could be described as the forced urbanisation and modernisation in the period after World War Two. As a consequence, a huge number of the rural population moved to the cities and took up employment in the industries. This migration, however, provoked a housing shortage. ${ }^{10}$ To remedy the situation, the State took upon itself to develop big residential areas consisting of blocks

\footnotetext{
9 On the topic of socialist rural-urban migration, see Dichev (2003).

10 With regard to the theory of the socialist economy as an economy of shortages, see more in Kornai (2012).
} 
of flats and reconstruct existing urban neighbourhoods by replacing the small houses and their little gardens with multi-storey buildings. And, because the main aim of the authorities was to accommodate people as fast as possible, the places around these blocks of flats were not attended to. The easiest and the cheapest way to finish these architectural projects was to encourage people to make small gardens and green spots with their own resources. Settling in the areas with blocks of flats was particularly ritualistic. The initial "chaos" had to be conquered by means of a series of procedures of rendering the newcomers "urbanised," establishing social and hygienic habits, with the goal to make the residents of cities and towns embodiments of the socialist person in the residential area. The collective initiatives, such as creating gardens in between the blocks of flats, building up the shared spaces, competing with other blocks of flats to be named "a model block of flats," etc., functioned as collective acts of offering a return gift. The discourse of representing these activities from the point of view of the residents themselves was likewise quite ritualistic. Taking care of shared spaces and shared gardens was closely related to the so-called "Lenin Saturdays" (cf. Crampton, 1997, pp. 251-252). These were specific forms of organised community work, in which workers, pupils, and urban residents in general regularly "volunteered" to work on a Saturday in order to improve the lay out in their residential areas and to keep the town (city) clean. Those Saturday shifts in honour of Lenin provided the mechanism for residents to create and maintain most gardens in front of their blocks of flats.

\section{The garden at the entrance - the shared urban green spot in the city}

The markers of urban life in the new residential areas were very few in the beginning, actually limited to a flat in the city, central heating, landline connection, and gardens in between the blocks of flats. Irregularities of construction and infrastructure were "compensated for" by the collective initiatives organised by the Fatherland Front ${ }^{11}$ the local Party organisation, or the City Borough Council. These "shared spaces" were created through cooperation of the citizens with the city institutions and social organisations, which was both an expression of the residents' "rights to the city" and a

\footnotetext{
11 The Fatherland Front (Otechestven front) was a mass organisation during the socialist period in Bulgaria (1944 - 1989), politically subordinated to the Communist Party, which blurred the Front's specificity and lessened its influence on the local communities, while still making it appear as another form of the political power of the state in the socialist period. The Fatherland Front used to have organisational units in all residential areas and in all villages, towns and cities around the country, and it organised quite a few of the communal activities in people's every-day and festive life.
} 
reflection of the "obligation of the citizens." Let me illustrate this by quoting from an interview with an administrator in the Trakia municipality, who worked there in the 1980s and the 1990s, when the residential area was a gigantic building site and the first residents were just moving in:

The obligation of the People's Council (Region Six) was to supply trees, bushes, flowers, seeds, for example, to mow the lawns and keep up the grass, to maintain the irrigation hydrants and provide the hoses to water the grass. Benches and water hoses were distributed among all, each block of flats had their own. This is the kind of organisation we had. To add to this, the municipality contributed towards collecting the rubbish, sweeping the pavement, especially at the bus stops, establishing the bus schedules, etc.; we provided machines, building materials, technical guidance, took care of the tracks leading to the entrances and of the pavements that people laid almost on their own. Children's corners and playgrounds, sports facilities, this kind of things were constructed. The spaces around the blocks of flats were distributed and residents knew which territory they were responsible for. We had the local branches and thus territories were divided. The Fatherland Front had local councils and it was a very good thing. They were obliged to keep up the trees and the bushes in the area. They helped planting those trees, bushes and flowers; they created the green corners, volunteered to take part in constructions, in organising pedestrian crossings, in providing access. Back then there were initiatives like "A real manager of one's territory." They would announce the winners. There were green patrols, pioneer groups.

Evangelina, 55 years old when interviewed in 2005; working for the Trakia municipality at the time of the interview

Administrative units, institutions and party structures used to control and direct peoples' everyday life in the residential areas in order to secure the citizens' participation in finishing off construction work. Yet, to compensate for the deficit of private space that would allow expressions of individuality, hybrid zones were also created: neighbours could take their lives out of the flats into the regulated space of the residential area. The principles of collective living in a socialist residential area were based on collective commitment to maintaining property because everyone was expected to husband the town or the city in equal measure. What was new was that in that case, husbanding did not mean ownership.

In socialist Bulgaria the housing property was the only private property that people could have. So, in terms of the private/public dichotomy, we can outline a specific division between the private (as "my home") and the public (as what is shared). Thus, the appropriation of what was shared was legally possible only in a ritualised form - creating a shared garden that could serve as a public space of communication and entertainment in front of the entrance to the block of flats; unofficially, however, this kind of gardening 
attested to informal leadership among the neighbours. In many cases, where the community of neighbours was not organised by formal or informal leaders, the areas around the blocks of flats were abandoned and some people appropriated small plots and started their vegetable gardens. These forms of unofficial privatisation of shared spaces provided a link between the village and the city (town), and mark the territories of rural-urban migrants.

The garden in front of the block of flats is usually on both sides of the front entrance and has flowers and trees planted in it. This is where the benches and the tables are and where neighbours gather. Using the single-family house analogy, this is the front yard, representative of the residents. Behind the blocks of flats where no entrances exist, the pertaining grounds are not kept up and are usually marked by wild vegetation that the municipality cuts several times a year. Occasionally, some of the residents use these "back yards" of the blocks of flats to plant vegetables in small fenced off green boxes. Another method of connecting the various storeys of the building with the ground is growing vines that hang over the balconies. The "vertical" gardens thus created transform the urban balcony into a house yard and protect the flat from the hot southern climate in town. ${ }^{12}$

A form of promoting local identity and a sense of belonging to the place is the combination of everyday and extra-ordinary gardening with a celebration. One of the activists of the Fatherland Front in the 1970s and 1980s relates the details of such a ritualisation taking place in a block of flats where the residents were also the owners of their respective flats. Plovdiv is situated in a wine region and a lot of the citizens are originally from the villages around, which means that they grow their own grapes and produce their own wine. Harvesting the grapes is a collective activity both in the village and in town, with neighbours and relatives taking part in it. In towns and cities, however, the individual is separated from his kin and must rely on the community of neighbours:

In block 31 - I hope I haven't mixed up the number - vines were planted. The vines developed impressive canopies, and there was a Mr G. from the Bulgarian Football Federation, he worked there. Every year, in autumn, they organised a festivity for everyone at their entrance, collecting the grapes. All the children were there, everyone was given a grape cluster, an improvised performance would be scheduled, and then cleaning the leaves; he used to spray the grapevines, and everyone watered

\footnotetext{
12 Megan Luneburg's observations and visual documentation on the uses of balconies in Trakia are quite interesting - as an architect. she is interested in the interaction between architects and residents: "Looking at the balcony, an everyday space negotiating private and public life, the photos focus on confrontations. Not only between these two realms, but also the confrontation of the architectural process, happening in a specific moment in time, and the inhabitation process, which survived the transitions and continues to thrive" (Lueneburg, 2015).
} 
them with a bucket in the summer; that's it. They considered it their own. Neither G. nor anyone else took home more than a cluster of grapes. Everyone was given a grape cluster. No one measured it: who got 600 grams of it and who got 500 .

Anna, 70 years old, a retired activist of the Fatherland Front organization, who worked in the neighbourhood between 1979 and 1989

\section{Green bits and "vegetable plots"}

Another official form of urban gardening is exemplified by the green areas around the urban districts, which were provided to the people willing to have their small vegetable plots. The rents for such places were modest but the competition to have access to them in the socialist period was severe. The "winners" in the contest were people who had good connections with the authorities. Plots for urban gardening were primarily allotted to people of merit or privilege, such as Communist Party campaigners, active members of the Fatherland Front organisations, associates working for the institutions, etc.

The produce from vegetable plots replaced the support that usually came from the villages in the form of food supplies, which helped the urban migrants "survive" in the new context. Through gardening, the people that lived in the newly built residential areas organised quite a portion of their urban life and socialised with those who shared their interests. As a result, it was not only the neighbours in the blocks of flats but also the gardening neighbours that were included in the reciprocitory assistance and giftexchange network.

In socialist times, the aesthetic and architectural regulations for space design were strictly applied and the general cityscape of Bulgarian cities and towns was more or less the same - with separate places for work, dwelling and leisure time. And, because leisure time areas were concentrated in the centre, people in the periphery developed their social networks and neighbourly relationships as practices to inhabit together the places they shared around the blocks of flats.

\section{The city in transition - making the city "from below"}

as After the collapse of the socialist project, a project which - it is important to note - remained unfinished, the following period of transition opened new possibilities with regard to the making of the city from below. On the one hand, the state was weak, the changes were very dynamic, the transformation of society happened not only in terms of property relations but also as social mobility and the heteronomisation of differences. From 
such a point of view, urban gardening was very interesting because of the possibilities for individuals to officially have access to the common spaces.

On the level of the urban surface, this period of crises - political, economic, and social, could be observed in many abandoned urban parks and gardens in Bulgaria. In other cases, because of the restitution of property, many green areas became private, and new post-socialist buildings appeared in the places of what had been playgrounds for children.

The lack of commitment on the part of institutions or citizens had its impact on collective habitation and garden maintenance. On the one hand, the economic crisis of the 1990s served as an excuse for cuts on the part of the municipal structures that lacked proper budgets - this, of course, meant hindrances in maintaining the city greens. The institutions that could organise volunteers and Lenin Saturdays were gone; there was no compensation for the lack of funds and human resources in the municipality. On the other hand, the citizens themselves were in a situation of drastic changes. They had to reorganise their everyday life and their immediate environment in the new political and socio-economic circumstances of a country in transition.

The crumbling of those ideological constructs which sustained collective living "here and now" and legitimised the model of the city, along with the search for new values that might bring the community together and provide a vision for the future, are symptomatic of a state of crisis. In conditions of a crisis, differences become increasingly apparent, various fields become heteronomous, homogenous communities are diversified, and institutions like the party system, social relations, professional communities, neighbours, families, etc. - lose their totalising function. When old institutions are dysfunctional, while the new ones are still inoperative due to the uncertainty as to where society might be heading, organised life in residential areas falls apart. Some neighbour communities keep acting collectively in order to maintain their environment but other groups of neighbours have nothing in common except the block of flats they share:

If you now go behind building 4 and 2 - onwards from ours (we're number 5), everything is in weeds. There is no path, nothing can be seen, it is all abandoned and neglected, like a piece of wilderness, only it is in between the blocks of flats. The paths that existed are gone - people used to take care of the trees...

Valeria, one of the "first settlers" in the residential area; working in education at the time of the interview (2004).

Urban gardening is a significant example of spatial transformations in residential areas and the problem of public-private ownership being complicated by the existence of semi-private, semi-public zones defined by 
constant negotiation between individual / personal interests through social and cultural types of usage.

Many of the activities related to the forms of appropriation of places in the residential area came as a result of pre-existing shortages or the incompleteness of the socialist project. Later on, when many of the socialist limitations and regulations were no longer valid, such activities resulted from the absence, or insufficient scope, of initiative and investment on the part of the local administration to compensate for the things lacking in the transition period. A case in point is the "gazebo in front of the entrance door." This space, generally accessible to everyone, is usually "occupied" by some of the residents, who know each other and spend some of their spare time together. These places are on the border between the public and the private dimensions of life in the borough: this is where news could be exchanged; this is where people play cards, watch football games or celebrate personal occasions. These places are a sort of "extension" of the space of the home (flat) in the shared space of the residential area in front of the building, where people can take out their food or drink, or their private life, to comment on their neighbours' lives and have them comment in their turn. But these places are, in a sense, public space because this is where the general meetings of owners take place, this is where decisions are made, conflicts are solved or reports regarding activities are presented. These liminal places, from the point of view of private and public life in the blocks of flats, have compensated for the lack of classical public spaces for social communication: cafés, restaurants and shops located outside the home space, in shared zones ("no man's land") in the street and the squares. This demonstrates how the period of crisis and transition is, at the same time, marked by creativity, social solidarity or conflicts and decision-making from below about how to use the places, how to negotiate the appropriation of the space and how to contest the boundaries between the public and the private.

\section{Urban gardening as post-modern inhabiting of urban space. The public (green) care and private (collective) activities}

In the recent ten years, the practices of inhabiting the city are more and more regulated and subordinated to different discourses. On the one hand, the state and municipal regulations for using the space have come to be strictly enforced, the property relations have been clarified, the privatisation of the common goods from the socialist times has been done and the blurred social and symbolic boundaries between the public and the private have been better defined. In such conditions, the places around the blocks of flats 
have become a collective private property and the neighbours have been organised in communities with a juridical registration. Any changes inside and outside the residential buildings should be authorised by a majority decision of the proprietors.

These legislative changes "normalised" the socialist communication between the state and the citizens via mediators, representative members of the neighbour community. ${ }^{13}$ Municipalities have been running many projects for systematic urban gardening and provided citizens with trees, flowers, benches to support them in rearranging the common spaces by their own efforts. Similar activities existed in the socialist period, too, but then everything was organised by the Fatherland Front, whereas now it is the multiple owners who have to coordinate and organise themselves. Thus, most of the cities and towns have implemented the idea that the shared spaces were the residents' common care and responsibility. In the last few years, urban strategies and master plans have provided a clear-cut perspective; thus, the involvement of the state has contributed towards making the cities greener and cleaner. On the other hand, the private proprietors were also engaged in the process (not only the neighbours in a building but also the private businesses in the neighbourhood, such as cafés, shops, etc.); they were now obliged to take care of the green areas and gardens around them. The active groups and associations, mobilised by the media and social networks, started running civic initiatives.

All these reforms, restrictions and "normalisations" changed the shared spaces inside the residential areas. Urban gardens in the peripheral zones were also transformed. After the restitution of land, these spots became private and they were used for the construction of houses or industrial buildings. The limited possibilities to rent land from the municipality have put the "urban gardeners" in a situation of competition that is much fiercer in comparison with the socialist and transition periods. Some of the earliest "lodgers" are retired people nowadays, still connected to the village, skilled in vegetable and fruit production. But in other cases, a kind of aesthetisation of their "vegetable plots" can be observed - they are arranged with flowers and such accessories as tents, tables and chairs, and have become places for relaxation and recreation, rather than mere means of food production. Despite the fact that the land is rented, the people that have been using it for

\footnotetext{
13 Replacing the socialist-time neighbour communities that had their representatives guided by the Fatherland Front, the Housing Act of 2009, which regulates multi-ownership in multi-storey buildings, requires that the owners of flats which share a staircase (or entrance, vhod in Bulgarian) in a block of flats should register an association of owners as a legal person. The Housing Act also regulates the maintenance of shared property, including gardens and spaces around blocks of flats.
} 
20 or 30 years feel these green bits to be their own places, gardens in the city of stones. This informal appropriation of public property leads to curious manifestations of social relations. There is a network of urban gardeners who support one another; they have created units of solidarity and mutual help: for instance, they take turns in watching over the gardens in order to prevent criminal invasions. To add to this, there is a kind of informal market of vegetable plots - some people renew their leases in order to control the access to the places for a longer period of time; to do so, they negotiate with the others.

The transformations of this type of urban gardening are part of the immaterial heritage of the city - the local know-how on "coming into property" of a tiny green bit of land, keeping it safe, cultivating it or renting it out. Along these lines, urban gardening is a specific form of Bulgarian urban dwelling.

Well, after a working week, they go there on Saturdays and Sundays and this is how it goes... Others rent it out. I know old Nadia, who lived with the Ivanovs, they were a family. When they moved to a flat in our housing block, the father died and old Nadia was the secretary of the Party unit. So she rented a spot of land. All seemed fine but one of her sons was not very well and was given a municipal flat to rent. She moved with him and the young family stayed here. There was a time when she turned the ground and did some work but after she moved, she let it to another family, in this block of flats again, to cultivate it. Something like a lease, only it is not theirs. I know of others, too... Everyone around here was a Party activist, you know. The X, Y, and Z families, they all had plots over there. The Ys have had one of them, you know, and they let it out on a lease or something. They operate with it unabashedly, and without any right, either. I don't know if anyone is out to get them or if anyone knows, or if anyone is interested in those plots of land at all. It is a fact that they haven't... Almost everyone has them. My neighbour Dimitrov had planted a special type of tomatoes so he brought a pink one for us to try. Old Vera, the children hate her because she hates them too, so they vandalise her strawberries and her tomatoes every now and again. She sows things and goes there with a bucket and a hoe all the year around to work on the vegetable plot; it gives a lot of fruit and veg. Tomatoes, syruped fruit..., fruit trees they've planted there... everything.

Irina, 55 years old, a Trakia resident

Even nowadays, most of the gardens still help the people survive in the tough economic conditions and serve as food supplies for many elderly people, mostly retired; still, there are some "new users" demonstrating alternative lifestyles. ${ }^{14}$ Despite the formal similarities with cooperative and community gardens well-known in Western Europe and in America, ${ }^{15}$ these "vegetable

14 Such users have embraced "homemade food," bio-products," etc. as their values.

15 Sandrine Baudry offers her detailed anthropological research on cooperative gardens in her 
plots" in Bulgaria have a different function. Like the Western cooperative and community gardens, the Bulgarian "vegetable plots" are meant to help citizens cope with situations of crisis and, in consequence, promote a sense of community, as well as mutual aid. Nevertheless, the latter came into being in the socialist period as a compensation for an outstanding deficit of private space, due to the lack of private property, and the limited access to the distribution of shared/municipal goods because of the ubiquitous system of privileges. Thus, the right to cultivate such a "vegetable plot" is an expression of privilege in the otherwise equal-rights society; it also secures a sense of privacy when using a green bit of the common municipal land.

Since 2010, another conceptualisation ${ }^{16}$ of urban gardening has acquired visible forms: it is related to the global discourses on the rights to town and the access to space. There have been initiatives on ecology, supported predominantly by young people from the rising middle class, who organise themselves with the help of social networks. Despite the dominant ideology of the collective, this type of gardening manages to express the individuality of every resident who wants to cultivate a plot of urban land. Several attempts have been made to create permaculture gardens or herb corners, and to run projects on urban gardening as a form of therapy for the stressed out citizens; these, however, are not significant urban practices as yet.

In conclusion I can say that, on the one hand, the study of gardening the city follows the main stream of political decisions, capital investments, and the privatisation of public spaces on the central level of the urban surface, as implementation of different visions of what the society and the city might be. Mostly, urban gardening in the socialist period was a compensatory mechanism to "fill up the empty spaces" in the cities. Empty not only in terms of missing physical infrastructure in the newly built residential areas or reconstructed central urban districts, but also in terms of lacking social infrastructure - places for entertainment, markets, cafés and restaurants. All these disadvantages encouraged the creativity of urban residents to find ways to live together and to inhabit the shared spaces. In the years after socialism, the reaction to these former disadvantages turned have resulted in the shrinking public spaces ${ }^{17}$ and the increasing density of buildings

doctoral thesis entitled Cultiver son jardin, s'inscrire dans la ville: Approche anthropologique des community gardens de New York City (Baudry, 2010).

16 Thus, the postmodern discourse overlaps with the previous ones.

17 Foucault defines his fifth principle of access to such spaces in the following manner: "Heterotopias always presuppose a system of opening and closing that both isolates them and makes them penetrable. In general, the heterotopic site is not freely accessible like a public place." (Foucault, 1984, p. 7). 
in the city (town) centres. The middle-class lifestyle values that began to emerge in Bulgarian society could be observed even in the gardens around the blocks of flats - instead of tomatoes and vegetables, garden accessories appeared in the shared spaces: small statues, "patriotic objects of material heritage," artificial springs, etc. A careful mapping of urban gardens can register the outset of social stratification of Bulgarian society even on the level of the visual material environment.

In terms of social relations that are hidden behind the appearance of shared places, urban individualism and collectivism could be analysed not only in terms of the division between the public and the private but also of the multi-voiced dialogue and negotiation between the state and its citizens, made possible by the civil participation of the people in the management of the urban territory. The different forms of urban gardening are a heterotopia and place of the memory of everyday life and ideology with its discursive constructions. They are the mirror images of local policies, but they are also very sensitive markers of global politics. Gardening the city means inhabiting the city. But, unlike consumerism, gardening involves getting rooted in the urbanity and reflects not only care but also the formation of local identity through place. This can be expressed by a symbolic and even physical fight for the places, appropriation of spaces, privatisation of the public, "New Age" activities and ideology, eco-mobilisation movements all at the same time and all centres around one place - the marginal space of the urban garden, neither only private nor entirely public, but shared.

\section{References:}

Baudry, S. (2010). Cultiver son jardin, s'inscrire dans la ville: Approche anthropologique des community gardens de New York City (PhD thesis). Université Paris-Diderot - Paris VII. Retrieved from https://tel.archives-ouvertes.fr/tel-00962486/ document

Bourdieu, P. (1977). Outline of a theory of practice. (R. Nice, Trans.). Cambridge: Cambridge University Press. http://ebooks.cambridge.org/ref/id/ CBO9780511812507

Bourdieu, P. (1980). Le mort saisit le vif: Les relations entre l'histoire réifiée et l'histoire incorporée. Actes de la recherche en sciences sociales, 32(1), 3-14. http://doi. org/10.3406/arss.1980.2077

Eyal, G., Szelényi, I., \& Townsley, E. (1998). Making capitalism without capitalists: Class formation and elite struggles in post-communist Central Europe. London, New York: Verso.

Foucault, M. (1984). Of other spaces, heterotopias. Architecture, Mouvement, Continuité, 5, 46-49. Retrieved from: http:/foucault.info/doc/documents/ heterotopia/foucault-heterotopia-en-html [Original publication: Conférence au Cercle d'études architecturales, 14 March 1967] 
Gell, A. (1985). How to read a map: Remarks on the practical logic of navigation. Man, 20(2), 271-286. http://doi.org/10.2307/2802385

Hannertz, U. (1980). Exploring the city: Inquiries toward an urban anthropology. New York: Columbia University Press.

Hirsh, E., \& O'Hanlon, M. (1997). The anthropology of the landscape: Perspectives on place and space. Oxford: Clarendon Press.

Kornai, J. (2012). What Economics of Shortage and The Socialist System have to say to the (Hungarian) readers today: An introductory study to the first two volumes of the life's work series. Acta Oeconomica, 62(3), 365-384. http://doi.org/10.1556/ AOecon.62.2012.3.5

Lueneburg, M. (2015, October 26). Inhabitants and balconies. Lobby. Retrieved November 12, 2015, from http://bartlettlobby.com/articles/ the-architect-the-inhabitant-and-the-balcony/

Parusheva, D., Marcheva, I., \& Zlatkova, M. (2010). Tinkering in daily life: People, state and social(ist) housing in Bulgaria. Etudes balkaniques, 3, 69-91.

Pinson, D. (2000). L"'usager" de la ville. In T. Paquot, S. Body-Gendrot, \& M. Lussault (Eds.), La ville et l'urbain: L'état des savoirs (pp. 234-244). Paris: La Découverte.

Shama, S. (1995). Landscape and memory. London: Harper Collins Publishers.

Shotter, J. (1986). A sense of place: Vico and the social production of social identities. British Journal of Social Psychology, 25(3), 199-211. http://doi. org/10.1111/j.2044-8309.1986.tb00724.x

Zrnić, V. (2009). Kvartovska spika: Značenia grada i urbani lokalizmi u Novom Zagrebu. Zagreb: Institut za etnologiju i folkloristiku Naklada Jesenki i Turk.

Zlatkova, M. (2001). Changes in urban neighborhoods in present day Bulgaria. Ethnologia Balkanica, 5, 185-193.

Zlatkova, M. (2011). The urban palimpsest, or how to study cities in transition: On a possible ethnosociological approach in urban studies. In M. Karamihova (Ed.), Readings in the history and culture of the Balkans in support of university teaching (pp. 271-284). Sofia: Paradigma Publishing House.

Crampton, R. (1997). Eastern Europe in the twentieth century and after. London, New York: Routledge.

Dichev, I. (2005). Prostranstva na zhelanieto, zhelanie za prostranstvo. Sofiia: IK „LIK“.

Dichev, I. (2003). Usiadaneto na nomadskiia komunizŭm: Sotsialisticheskata urbanizatsiia i formite na grazhdanstvo. Sotsiologicheski problemi, 3-4, 33-63.

Zlatkova, M. (2012). Etnosotsiologiia na grada: Po primera na grad Plovdiv. Plovdiv: Universitetsko izdatelstvo.

\section{Note}

The current paper presents results from my $\mathrm{PhD}$ thesis and the following observations as part of my research and teaching anthropological fieldwork activities at the University of Plovdiv, Bulgaria.

No coflicts of interest exist. 


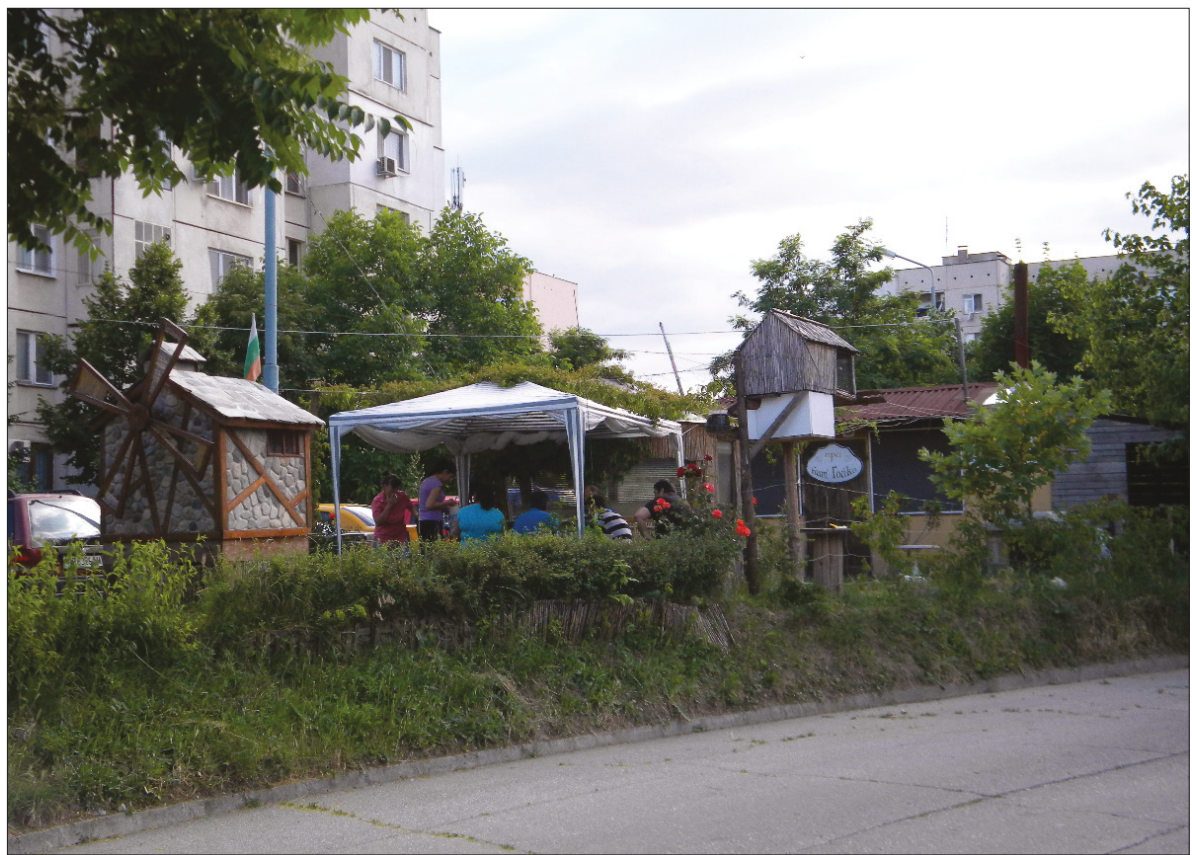

Pic. 1. Gazebo in front of the entrance door, 2015.

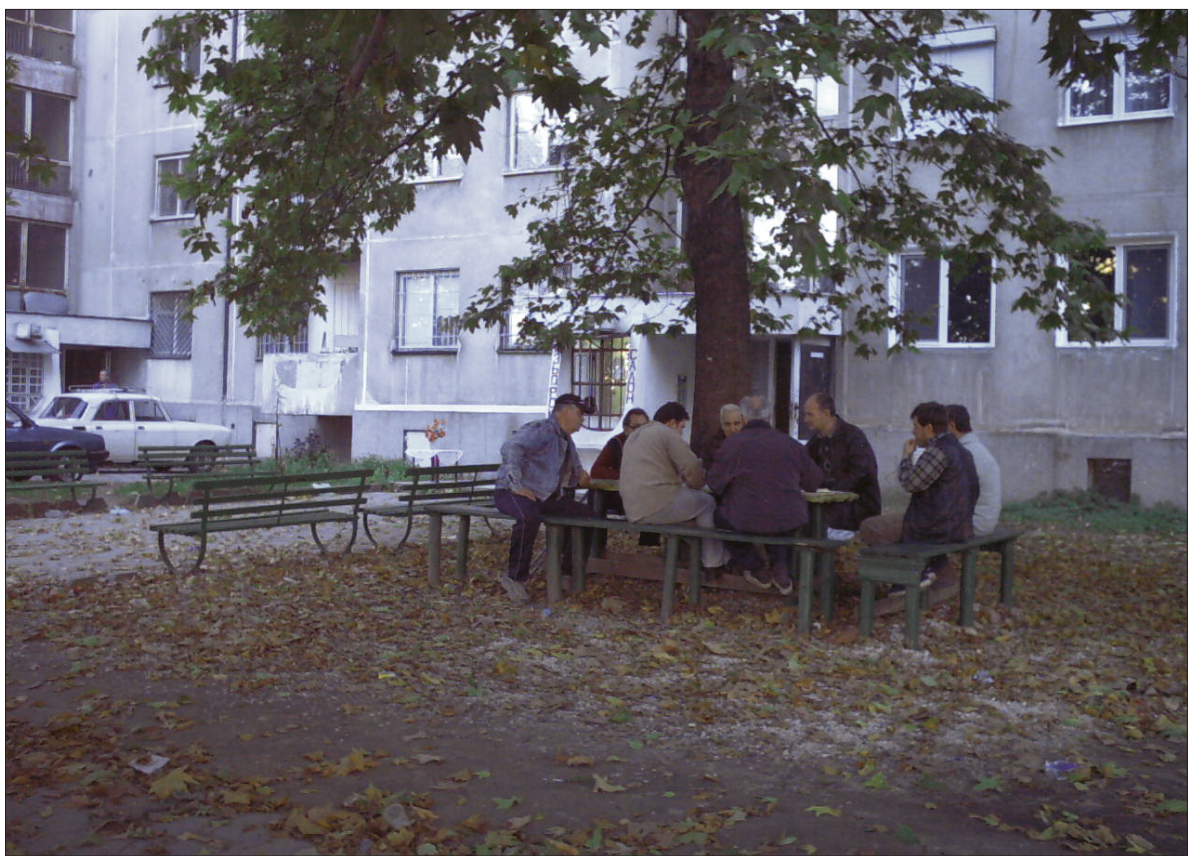

Pic. 2. Gazebo in front of the entrance door, 2002. 


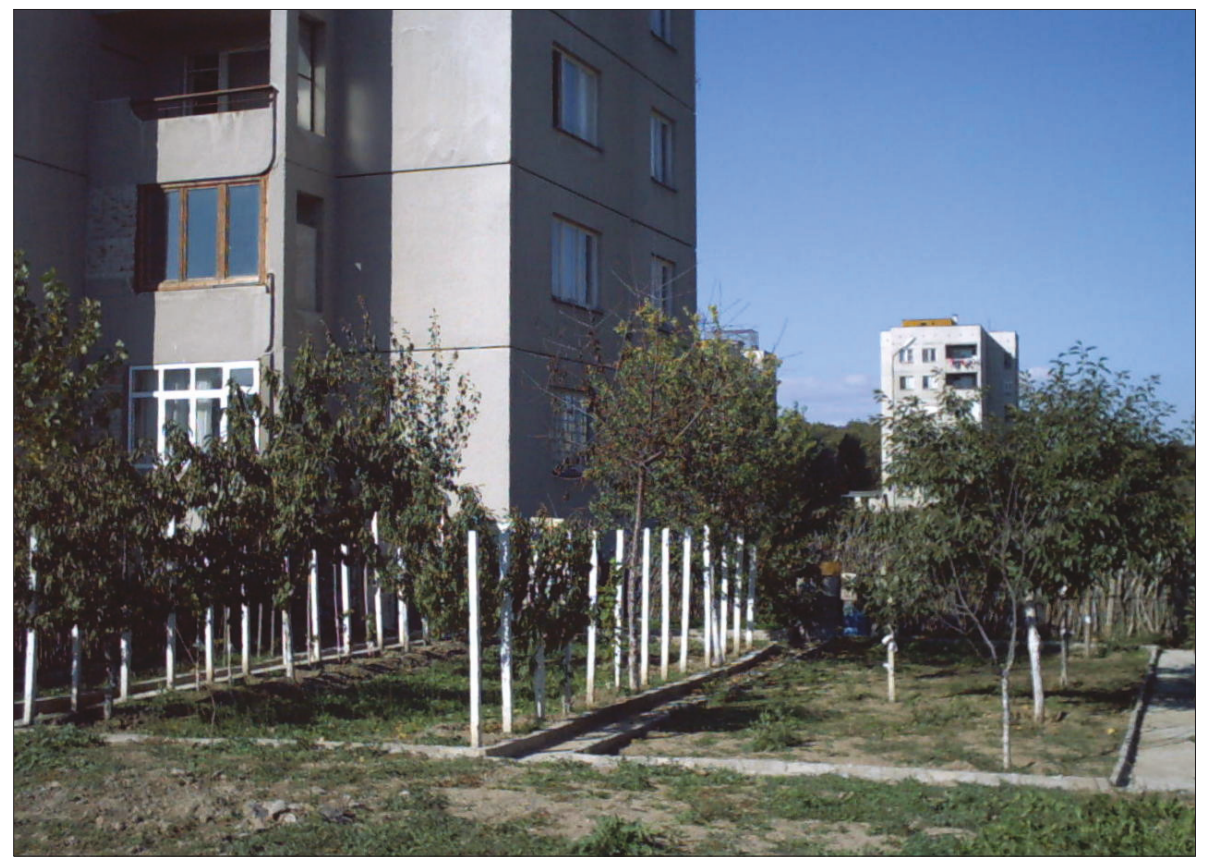

Pic. 3. A garden around a block of flats, 2002.

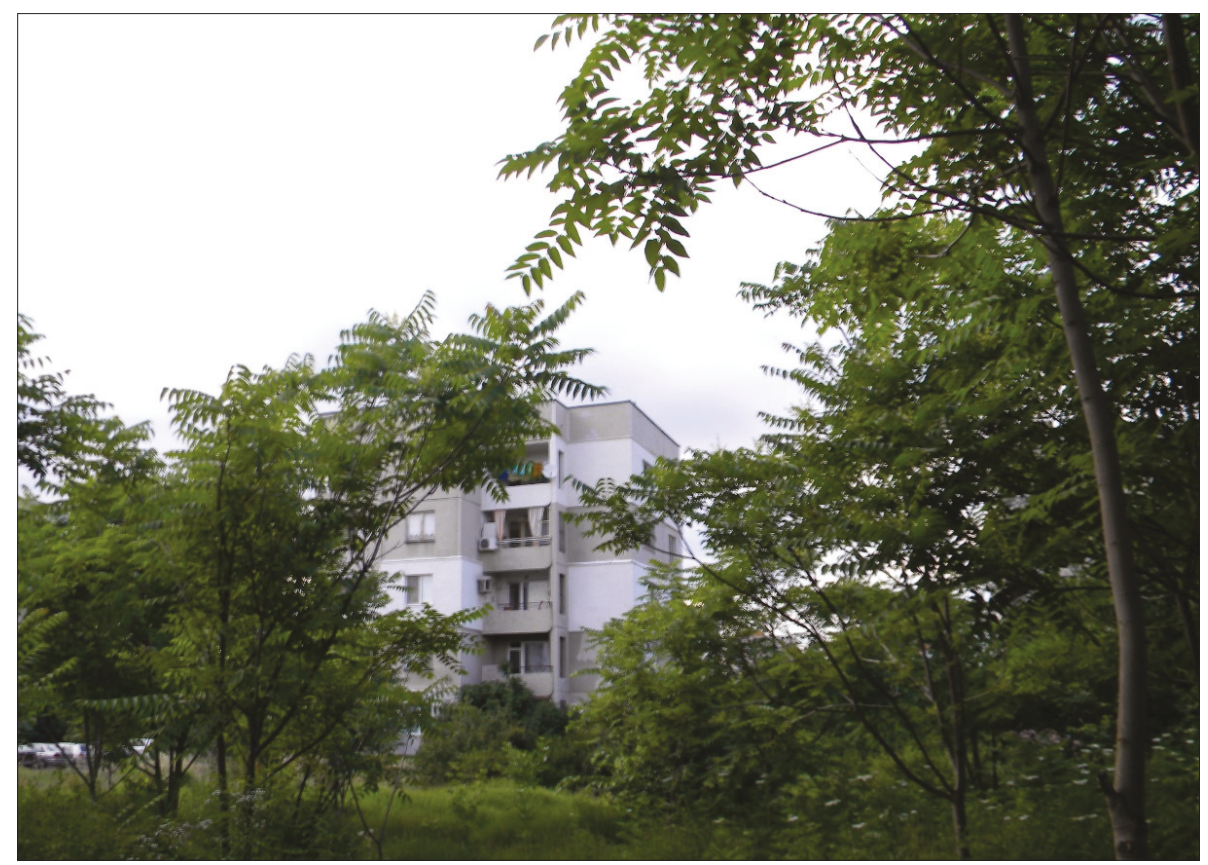

Pic. 4. The same garden around a block of flats, 2015. 


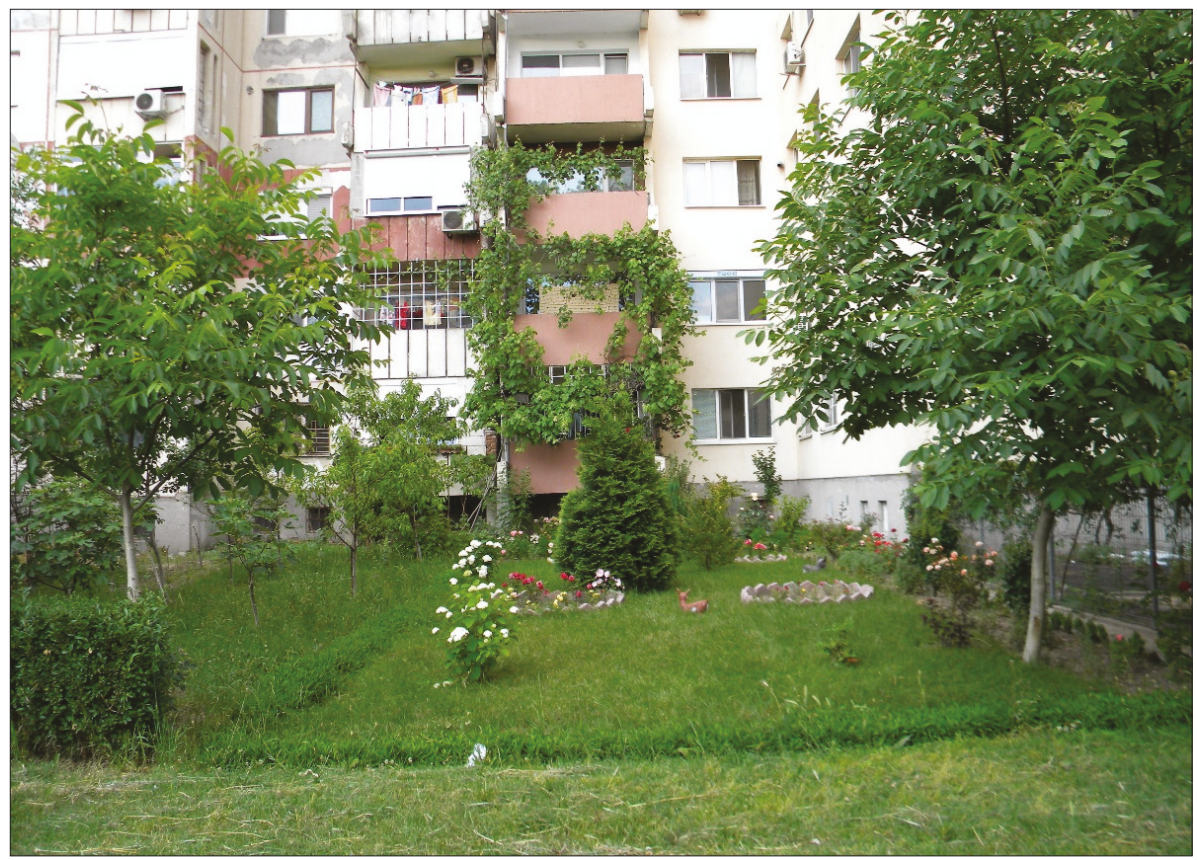

Pic. 5. A "vertical" garden and the balconies. 2015.

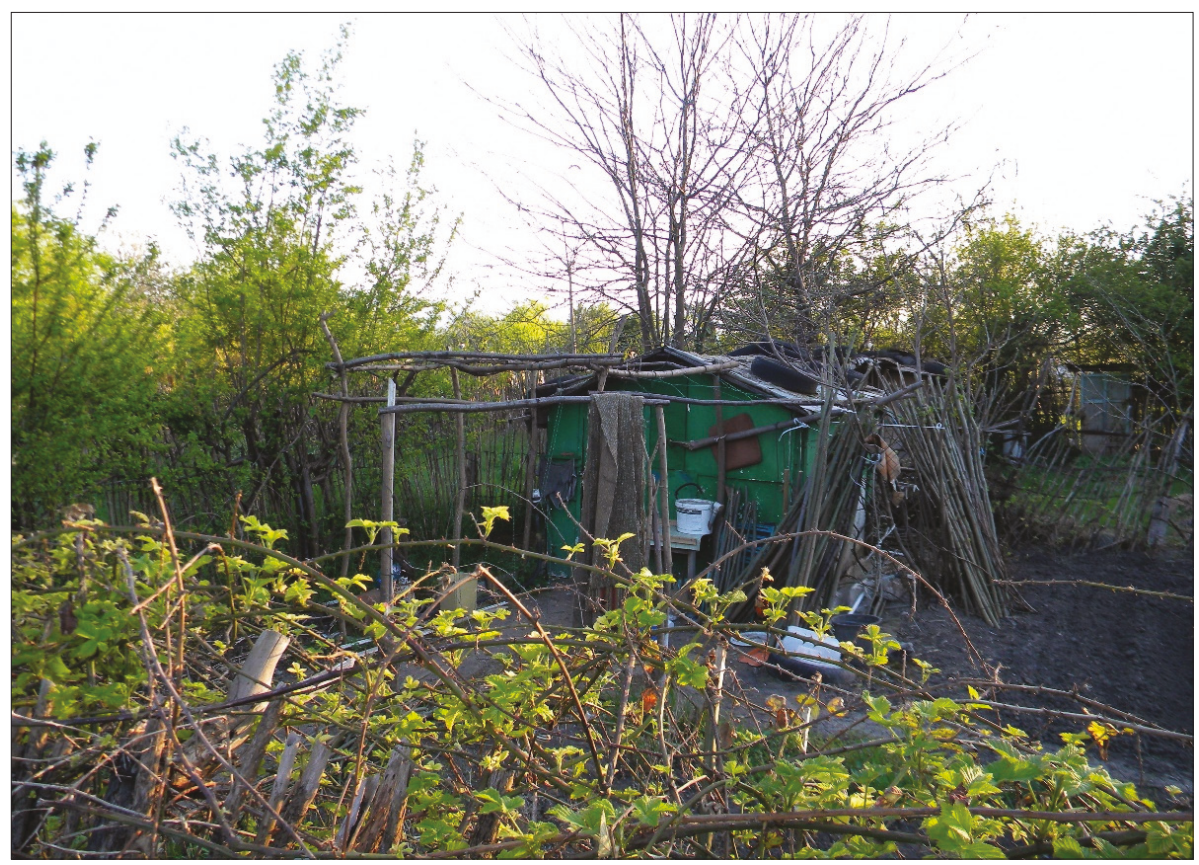

Pic. 6. A vegetable plot or so called "Ranche" 2015. 


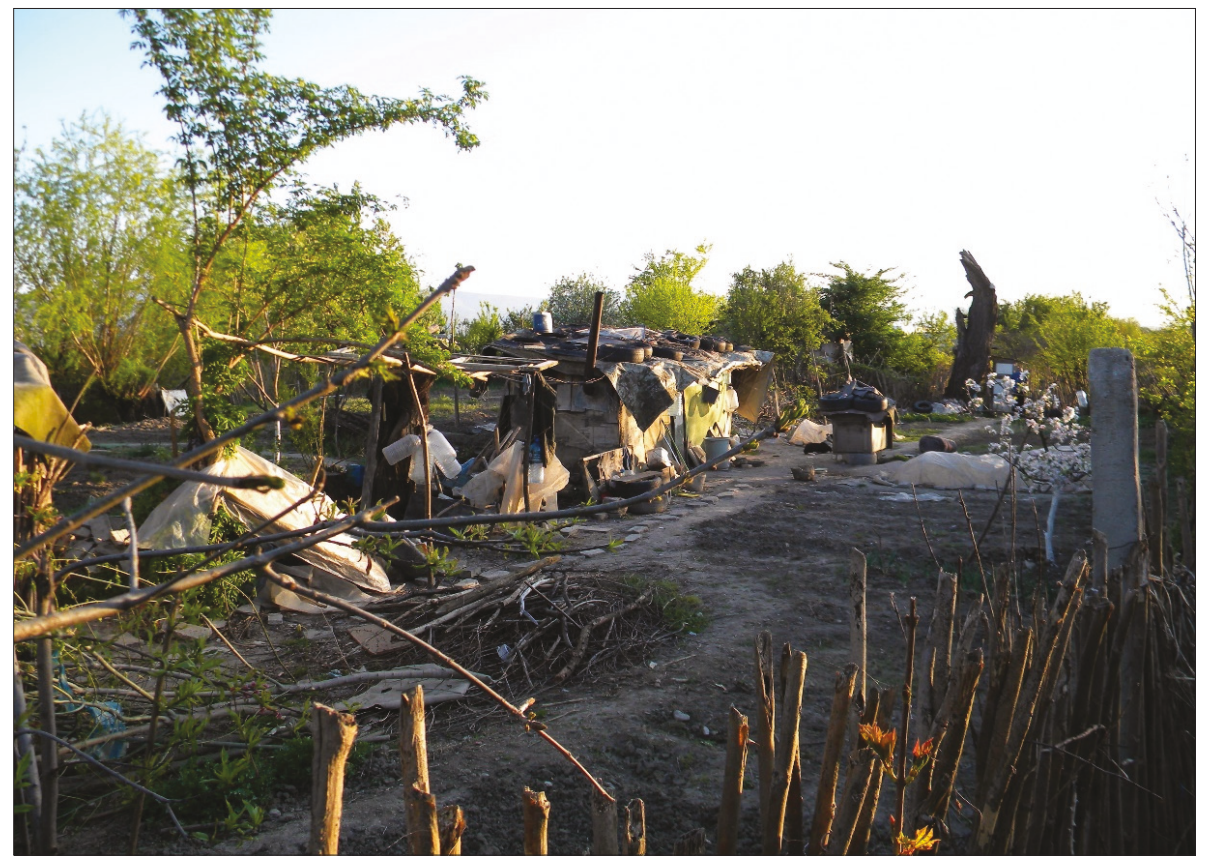

Pic. 7. A vegetable plot or so called "Ranche" 2015.

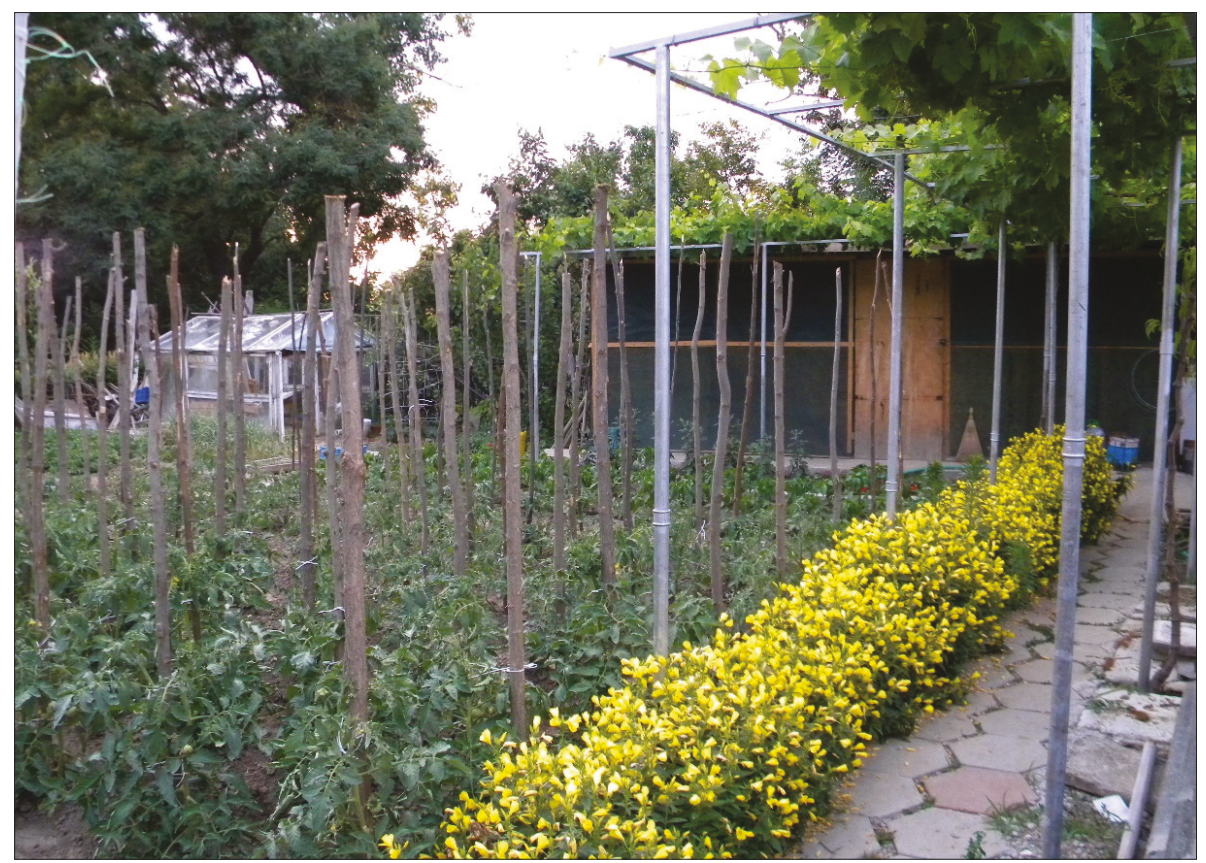

Pic. 8. A vegetable plot or so called "Ranche" 2014.

All the pictures done by the author. 